Cambridge University Press

0521006279 - The Cambridge Companion to Roman Satire

Edited by Kirk Freudenburg

Frontmatter

More information

\title{
The Cambridge Companion to Roman Satire
}

Satire as a distinct genre of writing was first developed by the Romans in the second century вСЕ. Regarded by them as uniquely "their own," satire held a special place in the Roman imagination as the one genre that could address the problems of city life from the perspective of a "real Roman." In this Cambridge Companion an international team of scholars provides a stimulating introduction to Roman satire's core practitioners and practices, placing them within the contexts of Greco-Roman literary and political history. Besides addressing basic questions of authors, content, and form, the volume looks to the question of what satire "does" within the world of Greco-Roman social exchanges, and goes on to treat the genre's further development, reception, and translation in Elizabethan England and beyond. Included are studies of the prosimetric, "Menippean" satires that would become the models for Rabelais, Erasmus, More, and (narrative satire's crowning jewel) Swift. 
Cambridge University Press 0521006279 - The Cambridge Companion to Roman Satire Edited by Kirk Freudenburg

Frontmatter

More information

\title{
THE CAMBRIDGE \\ COMPANION TO \\ ROMAN SATIRE
}

\author{
EDITED BY \\ KIRK FREUDENBURG \\ Professor and Chair, Department of the Classics, the University of Illinois \\ at Urbana-Champaign
}


Cambridge University Press

0521006279 - The Cambridge Companion to Roman Satire

Edited by Kirk Freudenburg

Frontmatter

More information

CAMBRIDGE UNIVERSITY PRES

Cambridge, New York, Melbourne, Madrid, Cape Town, Singapore, São Paulo

Cambridge University Press

The Edinburgh Building, Cambridge CB2 2RU, UK

Published in the United States of America by Cambridge University Press, New York

www.cambridge.org

Information on this title: www.cambridge.org/978052I 803595

(C) Cambridge University Press 2005

This book is in copyright. Subject to statutory exception and to the provisions of relevant collective licensing agreements,

no reproduction of any part may take place without

the written permission of Cambridge University Press.

First published 2005

Printed in the United Kingdom at the University Press, Cambridge

A catalogue record for this book is available from the British Library

Library of Congress Cataloguing in Publication data

The Cambridge companion to Roman satire / edited by Kirk Freudenburg.

p. cm. - (Cambridge companions to literature)

Includes bibliographical references (p. ) and index.

ISBN 0-52 I-80359-5 - ISBN 0-52 I-00627-9 (pbk.)

I. Satire, Latin - History and criticism. 2. Rome - In literature. I. Freudenburg,

Kirk, I96I- II. Series.

PA6095.C36 2005

$877^{\prime} .010932376-\mathrm{dc} 22 \quad 2004057024$

ISBN 978 O52 I 803595 hardback

ISBN 052 I 006279 paperback

Cambridge University Press has no responsibility for the persistence or accuracy of URLs for external or third-party internet websites referred to in this book, and does not guarantee that any content on such websites is, or will remain, accurate or appropriate. 


\section{Cambridge University Press}

0521006279 - The Cambridge Companion to Roman Satire

Edited by Kirk Freudenburg

Frontmatter

More information

Dedicated to all the self-deluded emperors, ideologues, bullies, and buffoons who make satire possible, pertinent, inevitable.

It's hard to not write satire. For who is so long-suffering towards this lopsided city, who is so iron-hard that he can hold himself back?

Juvenal, early second century CE

Here ... the daily panorama of human existence, of private and communal folly ... is so inordinately gross and preposterous ... that only the man who was born with a petrified diaphragm can fail to laugh himself to sleep every night.

H. L. Mencken, I922

If you aren't completely appalled, then you haven't been paying attention.

Election-year bumpersticker, Everywhere USA, 2004 
Cambridge University Press

0521006279 - The Cambridge Companion to Roman Satire

Edited by Kirk Freudenburg

Frontmatter

More information

CONTENTS

Notes on contributors

page ix

Acknowledgments

xiii

Notes on editions and abbreviations

$\mathrm{XV}$

Introduction: Roman satire

I

KIRK FREUDENBURG

\section{Part I: Satire as literature}

I Rome's first "satirists": themes and genre in Ennius and Lucilius

FRANCES MUECKE

2 The restless companion: Horace, Satires I and 2

EMILY GOWERS

3 Speaking from silence: the Stoic paradoxes of Persius ANDREA CUCCHIARELLI

4 The poor man's feast: Juvenal VICTORIA RIMELL

5 Citation and authority in Seneca's Apocolocyntosis ELLEN O'GORMAN

6 Late arrivals: Julian and Boethius JOEL RELIHAN

7 Epic allusion in Roman satire CATHERINE CONNORS

8 Sleeping with the enemy: satire and philosophy ROLAND MAYER 
Cambridge University Press

0521006279 - The Cambridge Companion to Roman Satire

Edited by Kirk Freudenburg

Frontmatter

More information

\section{CONTENTS}

9 The satiric maze: Petronius, satire, and the novel

VICTORIA RIMELL

\section{Part II: Satire as social discourse}

IO Satire as aristocratic play

THOMAS HABINEK

II Satire in a ritual context

FRITZ GRAF

I2 Satire and the poet: the body as self-referential symbol

ALESSANDRO BARCHIESI AND ANDREA

C U C CHIARE L L I

I3 The libidinal rhetoric of satire

ERIK GUNDERSON

\section{Part III: Beyond Rome: satire in English letters}

I4 Roman satire in the sixteenth century

COLIN BURROW

I5 Alluding to satire: Rochester, Dryden, and others

DAN HOOLEY

I6 The Horatian and the Juvenalesque in English letters

CHARLES MARTINDALE

I7 The "presence" of Roman satire: modern receptions and their interpretative implications

DUNCAN KENNEDY

\section{Conclusion}

The turnaround: a volume retrospect on Roman satires

Bibliography

Index 
Cambridge University Press

0521006279 - The Cambridge Companion to Roman Satire

Edited by Kirk Freudenburg

Frontmatter

More information

NOTES ON CONTRIBUTORS

ALESSANDRO BARCHIESI teaches Latin Literature at the University of Siena at Arezzo and at Stanford University, and is editor of the journal Studi Italiani di Filologia Classica. His research interests are Latin poetry, Roman culture, and literary theory. He has recently co-edited the three miscellaneous volumes Ovidian Transformations (I999), Iambic Ideas (200I), and Rituals in Ink (2004), and published a collection of essays entitled Speaking Volumes (200I), and contributed to various Cambridge Companions.

COLIN BURROW is Reader in Renaissance and Comparative Literature and Director of Studies in English at Gonville and Caius College, Cambridge. His publications include an edition of The Complete Sonnets and Poems for the Oxford Shakespeare (2002), and Epic Romance: Homer to Milton (I993), as well as numerous articles on the reception of classical literature in early modern England.

CAtherine Connors is Associate Professor in the Department of Classics at the University of Washington, Seattle, and the author of Petronius the Poet: Verse and Literary Tradition in the Satyricon (1998). She has published articles on Roman epic, Roman comedy, and the ancient novel, and her current research focuses on representations of nature and geography in literary texts.

ANDREA CUCCHIARELLI is a fixed-term researcher at the University of Siena at Arezzo. He has published articles on Lucretius, Virgil, Horace, and Petronius, and he is the author of two books: La satira e il poeta (200I), and La veglia di Venere-Pervigilium Veneris (2003, intro., trans., and commentary).

KIRK FREUDENBURG is Professor and Chair of the Department of the Classics, at the University of Illinois at Urbana-Champaign. His published works focus on the social life of Roman letters, and they include two books 
Cambridge University Press

0521006279 - The Cambridge Companion to Roman Satire

Edited by Kirk Freudenburg

Frontmatter

More information

C ONTRIBUTORS

on Roman satire: The Walking Muse: Horace on the Theory of Satire (I993), and Satires of Rome: Threatening Poses from Lucilius to Juvenal (200I). His current projects are a commentary on Horace, Sermones book 2 (for Cambridge University Press), and a study of libraries and literary histories in the Greco-Roman world.

EMILY GOWERS is University Lecturer in Classics at the University of Cambridge and a Fellow of St. John's College. She is author of The Loaded Table: Representations of Food in Roman Literature (1993), and is working on a commentary on Horace, Sermones book I for the Cambridge Greek and Latin Classics series.

FRITZ GRAF is Professor of Greek and Latin and a Director of the Center for Epigraphical and Palaeographical Studies at the Ohio State University. He works mainly on Greek and Roman religions. His publications include Nordionische Kulte (1985), Greek Mythology (1985; English trans. I993), Magic in the Ancient World (1994, English trans. 1997) and Der Lauf des rollenden Jahres. Zeit und Kalender in Rom (I997). He is currently working on a book on Apollo (to appear 2005) and on a study of Greek and Roman festivals in the eastern half of the Roman empire.

ERIK GUnderson is Associate Professor of Greek and Latin at the Ohio State University. He is the author of Staging Masculinity: the Rhetoric of Performance in the Roman World (2000) and Declamation, Paternity and Roman Identity: Authority and the Rhetorical Self (2003).

Thomas n. Habinek is Professor of Classics at the University of Southern California. His research focuses on the intimate relationship between Latin literature and the political and cultural practices of ancient Rome. $\mathrm{He}$ is the author of The Colometry of Latin Prose (1985), The Roman Cultural Revolution, co-edited with Alessandro Schiesaro (I997), and The Politics of Latin Literature: Writing, Identity, and Empire in Ancient Rome (I998).

JOHN HENDERS ON is Professor of Classics at the University of Cambridge, and Fellow of King's College. His recent books on Latin literature include Morals and Villas in Seneca's Letters (2004), The Roman Gardening Book (2004), Aesop's Human Zoo: Fables from Phaedrus (2004), Pliny's Statue (2002), Fighting for Rome (1998).

DAN H O OLEY is Chair of Classics at the University of Missouri. He is editor of the journal Classical and Modern Literature, and author of The Classics in Paraphrase: Ezra Pound and Modern Translators of Latin Poetry (I988), 
Cambridge University Press

0521006279 - The Cambridge Companion to Roman Satire

Edited by Kirk Freudenburg

Frontmatter

More information

CONTRIBUTORS

The Knotted Thong: Structures of Mimesis in Persius (1997), Roman Satire (forthcoming), and a number of articles on Roman poetry, classical reception, and translation studies.

DUNCAN KENNEDY is Professor of Latin Literature and the Theory of Criticism at the University of Bristol. A leading expert in the application of modern literary theory to the study of ancient texts, he is the author of The Arts of Love: Five Studies in the Discourse of Roman Love Elegy (1993), and Rethinking Reality: Lucretius and the Textualization of Reality (2002).

CHARLES MARTINDALE is Professor of Latin at the University of Bristol. He is the author of John Milton and the Transformation of Ancient Epic ( 1986$),$ Redeeming the Text: Latin Poetry and the Hermeneutics of Reception (I993), and co-author of Shakespeare and the Uses of Antiquity (1990). He is editor of Virgil and his Influence (1984), Ovid Renewed (1988), and (with David Hopkins) Horace Made New (I993). His forthcoming works include Shakespeare and the Classics, co-edited with A. B. Taylor, Cambridge University Press, and Latin Poetry and the Judgement of Taste: An Essay in Aesthetics, Oxford University Press.

ROLAND MAYER has produced a range of commentaries on Latin authors (Lucan, Seneca, Horace, and Tacitus), as well as numerous articles and reviews on literary and philological issues. For seven years he was an editor of the Classical Review. He is currently researching into the Roman value-concept of gloria.

FRANCES MUECKE, Senior Lecturer in Latin at the University of Sydney, is the author of Horace: Satires II (1993). She has written a number of articles on aspects of genre in Latin literature and is currently working on Humanist scholarship in late fifteenth-century Rome.

ELLEN O'GORMAN is Lecturer in Classics at the University of Bristol. Her published works include Irony and Misreading in the Annals of Tacitus (2000) and articles on Horace, Lucan, Ovid, Statius, Plutarch, and Helen of Troy. She is currently working on a book about the representation of Carthage in Roman literature, for readers interested in history, cultural history, myth, aggression, trauma, and narrative.

JOEL C. RELIHAN is Chair of the Classics Department at Wheaton College in Norton, Massachusetts. His published works include Ancient Menippean Satire (I993) and a new English translation of Boethius' De consolatione philosophiae (200I). The Prisoner's Philosophy, his literary study of 
Cambridge University Press

0521006279 - The Cambridge Companion to Roman Satire

Edited by Kirk Freudenburg

Frontmatter

More information

\section{ONTRIB UTORS}

Boethius' Consolation, will appear shortly from the University of Notre Dame Press. He is currently at work on a new translation of The Metamorphoses of Apuleius.

VICTORIA RIMELL is Professore a contratto in Latin literature at the University of Rome, La Sapienza, and was previously lecturer in classics at Girton College Cambridge, and Junior Research Fellow at University College Oxford. She is the author of Petronius and the Anatomy of Fiction (2002) and is currently writing books on Ovid and Martial, as well as editing a volume of Ancient Narrative on speech and writing in the novel. 
Cambridge University Press

0521006279 - The Cambridge Companion to Roman Satire

Edited by Kirk Freudenburg

Frontmatter

More information

ACKNOWLEDGMENTS

Now that this project, for so long just a rumor, has stepped into full public view, rather proud of its multi-colored jacket and mismatched pair of ISBNs, the book that it has become runs the risk of seeming considerably better adjusted and more "inevitable" than it really was, or ever could be. Pauline Hire proposed the idea of a Cambridge Companion to Roman Satire to me years ago, an idea that I regarded skeptically at the time, as a conundrum and a curiosity, certainly interesting, perhaps even worthwhile, but not terribly likely. Now that it is finished, I remain a skeptic, but fairly pleased with the end-result, glad to have done it, especially since the process of putting this act on paper has put me in touch with a good number of smart colleagues and friends, both old and new, who have caused me to rethink some of my own grand assumptions about what matters crucially to the study of Roman satire.

The standards set by the Cambridge Companion series are high, and a suitably serious attempt was made to meet them by the contributors of this volume. That said, I should make clear from the start that this book intends to serve its one most important purpose not as Roman satire's last word, but as a stalwart companion to those setting out to explore for themselves the genre's various regions, its topographical contours, and even its final frontier. Where you end that quest is your own business, and this book certainly does not propose to take you there. At best, it proposes to start you on your way, helpfully, along this line or that, if only to have you jettison it (let us hope inconspicuously) once you have found a route more direct, meaningful, and true. To do just that is good enough for us, and the stuff of a worthy companion. To do more would perhaps be too much, especially for an editor who has no truck with unilateral, empire-building schemes, such as this Companion could have easily become.

I cannot begin to recall in print the names of all who helped conceive, write, edit, and produce this book. But there are some whose impact demands special thanks, however terse. As always, Dan Hooley was much too nice 
Cambridge University Press

0521006279 - The Cambridge Companion to Roman Satire

Edited by Kirk Freudenburg

Frontmatter

More information

for his own good. Not only did he write a crucial chapter of the volume not even the one he wanted to write - but he worked hard to improve the volume's contents from beginning to end. The same can be said for Erik Gunderson who, though fully capable of keeping himself busy without any help from me, read whatever I asked him to read, sometimes repeatedly, and generously provided not just critical comments, but blisteringly smart insights that he alone has the brains to think up. Watching him, and John Henderson, think satire out of its classical box has been one of the more rewarding aspects of the behind-the-scenes work of this volume. Charles Martindale, a veteran of Companions past, was called upon for help of every kind, intellectual, technical, and bibliographical. He has been most patient with me, and gracious in providing help at every stage.

Much of the work for this volume was done during my year as National Endowment for the Humanities Rome Prize Fellow at the American Academy in Rome. Sincere thanks are owed to the Academy, to the College of Humanities at Ohio State University, and to the National Endowment for the Humanities for supporting my cause. Andrea Cucchiarelli, Sergio Casali, and Alessandro Barchiesi all did their best to ease me into l'altro mondo of Italian classics. On behalf of my entire family, I extend to them my sincerest thanks. Paulo Brozzi kept me well supplied with books, besides doing his utmost to improve my Italian. Finally, sincerest thanks are due to all the volume's contributors (thanks for your patience), and to Sinead Moloney and Michael Sharp at Cambridge University Press. By now, Michael, you should know better than to support my dubious cause. Mostly I behaved myself this time. Which isn't to say that this book is exactly what you had in mind. 
Cambridge University Press

0521006279 - The Cambridge Companion to Roman Satire

Edited by Kirk Freudenburg

Frontmatter

More information

\section{EDITIONS AND ABBREVIATIONS}

\section{Editions of Greek and Latin Works Frequently Cited}

Astbury, R. (I985) ed. M. Terentii Varronis Saturarum Menippearum Fragmenta. Leipzig.

Bieler, L. (1984) ed. Anicii Manlii Severini Boethii Philosophiae Consolatio, 2nd edn., Corpus Christianorum, Series Latina, xciv. Turnhout.

Clausen, W. V. (1959, rev. 1992) ed. A. Persi Flacci et D. Iuni Iunenalis Saturae. Oxford.

Degani, E. (1983) ed. Hipponax. Leipzig.

Eden, P. T. (I984) ed. Seneca Apocolocyntosis. Cambridge.

Holder, A. (I 894, repr. 1979) ed. Pomponi Porfyrionis Commentum in Horatium Flaccum. New York.

Keller, O. (I967) ed. Pseudacronis Scholia in Horatium Vetustiora, vol. II. Stuttgart.

Christian Lacombrade, C. (1964) ed. L'Empereur Julien: CEuvres complètes, vol. II, part 2. Paris.

Malcovati, H. (I930, revised I955) ed. Oratorum Romanorum Fragmenta. Turin.

Mynors, R. A. B. (1969) P. Vergili Maronis Opera. Oxford.

Olson, S. Douglas, and Sens, Alex (2000) Archestratos of Gela: Greek Culture and Cuisine in the Fourth Century BCE. Oxford.

Pfeiffer, R. (I949) Callimachus, vol. I: Fragmenta. Oxford.

Radermacher, L. (1907-65) M. Fabi Quintiliani Institutionis Oratoriae libri XII. Leipzig.

Shackleton Bailey, D. R. (I985) Q. Horati Flacci opera. Stuttgart.

Skutsch, O. (1985) The Annals of Q. Ennius. Oxford.

Vahlen, J. (1903) Ennianae Poesis Reliquiae. Leipzig.

Warmington, E. H., ed. and trans. (I935-40) Remains of Old Latin, 4 vols. Cambridge, MA/London.

Wessner, P. (I93I) Scholia in Iuvenalem Vetustiora. Leipzig.

West, M. L. (I989-92) Iambi et Elegi Graeci, vols. I-II. Oxford.

\section{Abbreviations and References}

ANRW Haase, W., and Temporini, H. (1972-) Aufstieg und Niedergang der römischen Welt. Berlin.

CIL (I 863-) Corpus inscriptionum Latinarum. Berlin. 
Cambridge University Press

0521006279 - The Cambridge Companion to Roman Satire

Edited by Kirk Freudenburg

Frontmatter

More information

EDITIONS AND ABBREVIATIONS

GLK Keil, H. (I 857-80) Grammatici Latini. Leipzig.

OCD Hornblower, S., and Spawforth, A. (3rd edn., I996) Oxford Classical Dictionary. Oxford.

OLD Glare, P. G. W. (I968-82) Oxford Latin Dictionary. Oxford.

RE (I893-I980) Realencyclopädie der classischen Altertumswissenschaft. Leipzig.

ROL Warmington, E. H. (1935-40) Remains of Old Latin, 4 vols. Cambridge, MA/London.

Sk. $\quad$ Skutsch, O. (I985) The Annals of Q. Ennius. Oxford.

SVF von Arnim, H. (1903-24) Stoicorum Veterum Fragmenta. Leipzig.

TLL (I900-) Thesaurus linguae Latinae. Leipzig.

W Warmington, E. H. (I938, repr. with corrections I979) Remains of Old Latin III. Lucilius, the Twelve Tables. Cambridge, MA/London. 